\title{
THE ROLE OF SOLVENTS IN THE LIVES OF KENYAN STREET CHILDREN: AN ETHNOGRAPHIC PERSPECTIVE
}

\author{
Joseph Cottrell-Boyce
}

School of Oriental and African Studies, University of London

\begin{abstract}
This paper explores the use of solvents among a group of street children in Ruiru, a satellite town of Nairobi. Solvent use is functional- dulling the senses against the hardship of the streetyet it also provides a link to the support structure of the 'street family' as a potent symbol of shared experience. Organisations working to rehabilitate street children are criticised for failing to appreciate the social context of solvent dependence amongst street children. Dependence on glue is preceded by dependence on 'street families', therefore organisations working to rehabilitate street children need to ensure they work through, rather than in conflict with, the 'street family'.
\end{abstract}

KEY Words: Solvents, street children, Kenya, ethnography

\section{INTRODUCTION}

There are an estimated 250,000 street children in Kenya and over 60,000 in the capital Nairobi (Consortium for Street Children, 2004). 'Glue sniffing' the UN notes, 'is at the core of "street culture" in Nairobi', and the majority of street children in the city are habitual solvent users (UNODCCP, 1999; p. 83). Despite its prevalence, very little research has looked at substance use amongst street-children. This paper assesses both the functional 'benefits' of solvents to street children and the role which solvents play in maintaining group solidarity on the street. Solvent use is often cited as a primary cause of high drop-out rates in projects set up to help street-children. It will be argued that in order to be effective, organisations working with street children need to acquire a more nuanced understanding of the social context of solvent dependence.

The paper focuses on the experiences of former and current street children in Ruiru, a satellite town of Nairobi, located on the Thika road about three kilometres from the outskirts of the capital, where I have been involved with a street-child rehabilitation project ${ }^{1}$ since 2004. A group of thirty street children were interviewed informally on the street over the course of several days. The interviews were recorded to be transcribed and translated later. More detailed interviews were conducted with three former street boys; 'Gitau', 'Ndungu'

1. Many homes for street children in Kenya are called 'rehabilitation' centres- this does not mean they offer drug rehabilitation.

Corresponding author: Joseph Cottrell-Boyce BA (Hons), London School of Economics, Houghton Street, London, WC2A 2AE . E-mail: JCBoyce@live.co.uk; Phone: +44 7920482815 
and 'Josphat' (all names have been changed to protect participants identities). In addition 'Gitau' and 'Ndungu' acted as research assistants, facilitating interviews, making introductions and translating from Gikuyu to English. All participants were made aware of the purpose of the interviews and consent forms were obtained.

\section{CHILD HOMELESSNESS: THE WIDER CONTEXT}

Rapid and unsustainable urbanisation in the postcolonial period led to entrenched urban poverty in cities such as Nairobi, Kisumu and Mombasa. In recent decades Structural Adjustment Policies (SAPs) have 'enforced policies of agricultural deregulation and 'depeasantization" which according to Davis accelerated the "exodus of surplus rural labour to urban slums even as cities ceased to be job machines' (2004; p. 6). 'Politically instigated ethnic clashes' in the 1990's during the Moi regime resulted in thousands more people pouring into slums which were already characterised by stagnant poverty (Mugo, 2004; p. 9); a situation which was repeated in the aftermath of the 2007 election violence. According to the UN two out of five African slum dwellers live in 'circumstances deemed to be life and health threatening' (UN-HABITAT, 2003; p. 12). 'The effect of absolute poverty in families is usually dehumanizing and devastating' writes Suda, 'when families are unable to provide their children with basic needs (food, shelter, clothing, love, health, education, security, etc.) some children may decide to turn to the streets' $(1997 ; 2$ p. 05). In addition to this, rural-urban migration has broken up extended families which in the past acted as 'a support network that took care of all cases of abuse, neglect and abandonment of children' (Mugo, 2004; p. 2). In the past children would have been cared for by aunts or grandparents if their biological parents died or were unable to care for them; now, they often have nowhere to go but the street. To Suda, the decline of kin-based support systems 'as a result of the larger social, cultural and economic transformations that are underway in contemporary Kenya' is key to explaining the existence of street children (1997; p. 202).

\section{SOLVENT USE IN RUIRU}

I was told by Gitau and Ndungu, and estimated from my own observations, that there were between 70 and 100 children living on the streets of Ruiru. Anyone walking around the town can observe street children in noisy groups, hanging around the central matatu terminus. Nearly all the children will openly be sniffing solvents; using their teeth to hold the neck of a dirty bottle to their nose, inhaling constantly throughout the day. The most common form of solvent being used in Ruiru is an industrial glue, used by shoemakers to attach rubber soles. Petrol is also commonly used, and is sometimes mixed with glue to stop the latter solidifying. When I asked the assembled group of street children if any of them did not use glue at the beginning of my interviews the answer was a unanimous 'No'.

'When you are taking glue life becomes easier' Gitau explained to me, 'For example I don't think a normal person can go there and just stay like those street boys'. Glue plays a hugely important role in the lives of street children, dulling their senses against intolerable conditions. The World Health Organisation (WHO) acknowledges that drug use amongst street children is 'functional in most circumstances', and explains that drugs are often used to 'anaesthetise physical or emotional pain, or to replace the need for food' (WHO, 1993; p. 16). 'You don't feel like eating', Gitau continued, 'you just feel like sniffing, sniffing, sniffing... you don't have time to think about food... at night you can't feel even cold... even you can sleep outside, when its raining and maybe you could not know it is raining'. Ndungu continued on the theme, explaining how as a street child sniffing glue had desensitised him to insect bites, beatings 
from older street boys or the police and the general pain and discomfort associated with life on the street. Ndungu also explained that staying high on glue had helped him deal with the inevitable loss of dignity which living on the street entailed; 'on the street it is very hard to clean yourself, you don't have a clean clothes... but when you sniff glue you can be dirty, and go to beg from people and not care'. Solvents can be found playing a similar functional role amongst street children in many developing countries, in Egypt for example Nashaat Hussein reports that street children also sniff glue 'to endure hunger and pain' (Hussein, 2005; p. 21).

'You see a lot of problems there and I think this is the best... this is the very big thing which they see that they can do; to use drugs, so that you can remove the stress' Josephat told me. The stress which Josephat referred to was not just the trauma of everyday street life, but past family traumas which had led him to the street in the first place. 'Domestic violence is frequently a factor in the presence of street children', writes Suda, 'children who find their home life deeply unhappy and unsafe may choose to leave' (Suda, 1997; p. 211). Violence and abuse appears have pushed many of the children in Ruiru onto the street; both Josphat and Ndungu stated that the violence inflicted on them by their respective stepfathers was what initially caused them to flee their homes. Ndungu referred to a specific incident when his stepfather had drunkenly attacked him with a panga (machete) as triggering his departure from home at the age of nine. Josephat explained that he started to use glue heavily from his very first days living on the street, 'in order to avoid thinking about my family'. Samuel, a nine year old still living on the street also indicated that he used glue to block out traumatic experiences; 'It makes me forget many things', he explained, 'It makes me see life as just $\mathrm{OK}^{\prime}$.

Both Ndungu and Josephat emphasised that the most difficult aspect of their lives on the street had been constant and at times unbearable fear. Children living on the street are extremely exposed and vulnerable, without shelter or the protection of a family, and a major part of the fear they experience relates to very real physical threats to their existence. As Josephat told me, 'most of the time someone is being harassed, either by police or just people passing there because they see that street boys, they take him, or her as a person who is not supposed to be alive.' When one of a group of street children I was talking to broached the subject of police harassment the rest erupted into a tirade of complaints, shouting over each other with accounts of brutality and pulling up their tops to display scars and bruises from routine police beatings. Aside from this younger street children are pray to violence and exploitation from groups of older street dwellers. Gitau still bears the scars from a fateful night when older street boys burnt his legs with petrol as he slept, a popular prank. A ten year old named Titus's face was severely disfigured from a similar burning. Some of the younger street children expressed other fears; of devil worshippers and witches who sacrifice or eat children. Their accounts give some insight into how terrified and powerless these minors must feel, exposed to lurking dangers in the pitch black night. Again, parallels can be drawn between street children in Ruiru and their counterparts in Egypt where 'children urinate at night while sleeping, have constant nightmares, and many of them cry for a long time for no particular reason' (Hussein, 2005; p. 45). In Egypt a street boy named Nader reported that 'children sniff glue to escape their fears' (Hussein, 2005; p. 46), and this also seems to be a primary reason for using solvents in Ruiru. Solvent use keeps normal consciousness at bay and therefore removes the fears which would otherwise weigh heavily on children's minds. 'The main benefit of taking glue', Ndungu states, 'is to stop fear and to stop thinking'.

The specific medical conditions associated with solvent abuse were not properly understood by most of the street children questioned, yet the majority seemed to grasp that glue use presented serious, and potentially 
lethal health risks ${ }^{2}$. Indeed a popular, if unfounded, belief amongst the street children was that glue use caused cancer. The children also stressed that being under the influence of solvents presented other hazards, aside from the direct risks of inhalation. 'When you mix glue with petrol it can make you mad', a boy named John told me, 'You can walk into a busy road and you are not aware of the vehicle, and so you are killed' Awareness of the dangers of solvent abuse did not dampen their enthusiastic consumption of glue however.

\section{THE SOCIAL CONTEXT OF DEPENDENCE}

While it is vital to grasp the functional role of solvents, to obtain a deeper understanding of the significance of glue to street children it is necessary to look beyond the relationship between the individual and the substance, and examine the social processes which surround dependence. Most of the children interviewed stated that they had had no contact with drugs prior to their arrival on the street; but that once they arrived they had been introduced to solvents very quickly by fellow street children. Samuel explained that a boy of his own age, 'Kimani', supplied him with free glue for his first few days on the street, telling him 'When you take this you won't feel shy' ${ }^{3}$. For children

2. Solvent abuse, The World Health Organisation reports, presents a grim spectrum of risks to habitual users, including but not limited to kidney dysfunction, peripheral nerve damage, brain damage, liver dysfunction (including hepatitis), lung dysfunction and lead poisoning (WHO, 1992; p. 4). The most immediate risk facing glue using street children is 'Sudden Sniffing Death Syndrome', were solvent inhalation can trigger severe cardiac arrhythmia, killing the victim in seconds (WHO, 1992; p. 4). While the health risks presented by solvents are well documented, it must be noted that very little research has specifically looked at the impact of solvents on the health of street child populations. The WHO notes that while 'the use of substances is relatively widespread - if not universal - among these children, little is actually known about the effects of inhalants and other drugs... on children before they enter puberty' (WHO/ NIDA, 2000; p. 12).

3. When we asked the whereabouts of 'Kimani' and another boy named 'John', who Ndungu said had introduced him to glue, both were said to be dead. such as Samuel, who knew nothing of the effects of solvent use, the primary reason for initial use was to fit in and be accepted by other street children. 'Staying separate' Ndungu, Gitau and Josephat concurred, would leave a street child extremely vulnerable to the very real dangers mentioned above. New arrivals to the street quickly realise the vital importance of joining a 'base'; the location were a group of street children sleep and socialise each night, staying together for safety ${ }^{4}$. Typically between five and ten individuals gather at a base, constituting what street children themselves term a 'street-family'. Kilbride notes that in Nairobi street boys 'regularly sleep with age cohorts' (Kilbride, 2000; p. 86), and Ndungu confirmed that this is generally the case with bases in Ruiru too. Most newly arrived children accept glue sniffing as a non-negotiable condition of membership of a 'base'. 'When you go there the first thing you are to do is to take glue', Gitau explained, 'that is the only time you are accepted in a certain base'. Similar situations appear to exist in other developing countries, in Egypt for example Hussein states that 'the use of inhalants... accelerates the process of immersion into street groups' (Hussein, 2005; p. 45). Any reluctance on the part of street children to use drugs is usually far outweighed by the fear of being isolated from the group.

To fully comprehend why street children use glue, it is necessary to appreciate how reliant individually weak and vulnerable street children are on the 'street-family'. In the United States sociologists have suggested that the street gang in deprived inner city neighbourhoods may act as a 'substitute for poorly functioning familial structures; its value orientation offers a moral chart for those youths excluded from mainstream cultural systems' (Venkatesh, 1997; p. 89). A similar substitution can be observed amongst street children in Ruiru, yet as they are more vulnerable and even more excluded than their American counterparts they are far more reliant on the

4. The 'base' shown to me was the abandoned shell of a car where a group of eight boys in their mid teens slept, two of them in the vehicles boot. 
substitute family structure. Aside from providing protection and the safety of numbers, the group provides friendship and mutual support; food and other resources are shared and members show genuine concern for each other's welfare. On one occasion in 2004, a street boy from Ruiru ran five kilometres to the children's home where I was volunteering at the time, to ask for assistance for his friend John Mageri, a diabetes sufferer. When we went to Ruiru later that day we found John very ill, surrounded by his 'street-family' who were doing all they could to ease his suffering. Comparisons may be made with street children in Brazil most of whom belong to a 'turma'; 'a close-knit group that provides youngsters with support, companionship, and protection' (Campos et al, 1994; p. 323), and performs 'many functions usually fulfilled by the family'(Campos et al, 1994; p. 328).

The WHO acknowledge that street children use solvents 'because of peer pressure' and 'to socialize' (WHO, 1993; p. 31), yet 'Peer pressure' does not adequately convey the intense coercion which children on the streets of Ruiru face. 'If you are a street children [sic]', Gitau stated straightforwardly, 'glue is like a rule'. Josephat agreed, insisting that refusing to use glue was simply not an option on the street: 'When you go to the street and you don't take glue you could see yourself as someone who is foolish... most of them cannot accept you to be one of them because you are not using this thing'. The same coercion may be observed among children in similar circumstances thousands of miles away; within the Brazilian 'turma' 'group solidarity is enforced by various mechanisms... New members have to... prove their willingness to abide by group norms, and norm breakers are punished' (Campos et al, 1994; p. 323). The functional effects of solvents enable street children to cope with intolerable conditions; in Gitau's words glue sniffing made life 'easier'. Each member of the 'street-family' has a vested interest in the other members' survival and ability to cope on the street as they are dependent on them for security and support. It is therefore logical for a street child to put pressure on his/ her fellow street children to use solvents. A street child who did not use glue might find it difficult to beg, complain of hunger or be overcome with fear at night. Their 'normal' childish behaviour, unmediated by solvents, would be a burden on the 'street-family'.

Josephat recalls that when he first arrived on the street he 'thought [glue sniffing] was the very best thing that I could also relate to them, and be like them, like street boys', an admission which coveys how central solvent use is to the collective identity of street children. Living on the margins of society, without families or homes, the glue bottle acts as a potent emblem of belonging; an indicator of shared experience and symbol of solidarity with the 'street-family', in the face of rejection and hostility from wider society. In-group conformity, manifested in glue sniffing, appears to create a sense of security. As Ndungu told me; 'the main importance of taking glue, when you are still in a street, it's like a, let's say a bond; it used to bring us together. Because they believe that when you are taking glue you become one of their members'. Similarities may be drawn between street children in Kenya and habitual users of harder drugs such as crack cocaine and heroin in the West. In both cases the individual's life is orientated around a drug which is the defining characteristic of his/ her social group (see U.S. Congress, 1994; 126). In Ruiru, a child who did not use glue would not be considered a true street child and would therefore leave themselves vulnerable to the distrust of other street children. Specifically, Josephat explained that he/ she might be suspected of being a snitch: 'You don't seem to be one of them... they could think even you are the one who go and tell for example police... to be given a small thing [money]'. Such suspicion is a symptom of the constant fear which characterises street life: Experiences of abuse from the police and general public teach street children that those who are not 'one of them' automatically have the potential to harm or exploit. Ndungu recalled that in his youth there was one child who stopped using glue due to headaches, and as a result 'the group members they decided to send him away from street'. 
Just as significant as the social pressure to use glue is the pressure to share glue. 'Where now if you don't have glue', Ndungu told me, 'the other friends now, let's call them your family because now that is the family we were living with, they could share... it was very hard to see someone without glue because of that sharing.' Around Ruiru, children can frequently be observed swapping and borrowing each other's glue bottles, so that even those who have not managed to acquire their own supply of glue for the day appear to be no less under its influence. In many cases children use glue heavily from their very first days on the street, but do not begin to purchase it until further down the line, relying instead on the generosity of their 'family'. Komter highlights 'the importance of sharing basic resources such as bread... in order to form and maintain social ties' (Komter, 2005; p. 201); to street children in Ruiru glue may be considered an even more basic resource than bread. Ndungu explained that 'our first priority it was glue', and that any money from begging and casual work would be spent on solvents, 'because for food we could rely on leftovers'. The sharing of glue displayed by street children in Ruiru fits Sahlins model of generalised-reciprocity were 'goods', in this case glue, 'move one way, in favour of the have-not' (Sahlins, 1972; p. 194), ensuring that every member of the group can meet their need for glue. Generalised reciprocity is more commonly associated with tight knit kinship groups; its existence amongst street children is indicative of the strong social bonds which hold street-families together.

\section{AGENCY RESPONSES TO SOLVENT USE}

It is widely acknowledged that there is insufficient research into substance abuse amongst street children (see WHO/ NIDA, 2000), and in the absence of research much of the advice and guidance given by the WHO and other bodies to NGOs working in developing countries is based on research into substance abuse conducted in Western countries. A WHO training package for dealing with substance use among street children contains directions for 'motivational interviewing' methods which are adapted from techniques outlined in a British study by Jarvis et al. (1995) (WHO, 2000b; p. 6); scan the bibliography of the same booklet and you will find Australian, British and America studies on substance use, but not a single study specific to a developing country (WHO, 2000b; p. 40). Solvent abuse became a source of concern in Britain in the 1980's, when high levels of use were observed among adolescents. Research at the height of Britain's solvent use 'epidemic' revealed that the vast majority of users only inhaled solvents a few times a week; only 2- 6\% used every day (Watson, 1986; p. 41). Most users also reported that their 'sniffing' sessions lasted less than 30 minutes (Watson, 1986; p. 42). In the USA during the same period solvent abuse was regarded as a 'Short experimental phase in the lives of a small proportion of children' (Watson, 1986; p. 28), an assessment which justifies the general view of solvents as low status drugs in the West.

Recalling his own childhood on the street Ndungu told me 'as for glue, we used to use every day, every minute'. When questioned about the frequency of their use the children living on the streets of Ruiru today also revealed radically different patterns of solvent use from their Western counterparts: 'I take it continuously', one boy answered, 'just for as long as I am awake' replied another. The WHO claim that 'at most, some children are regular or experimental [solvent] users, few are dependant, and most do not meet criteria for 'dependence' in developing countries' 5 (WHO, 1996; p. 101). This assessment, which presents solvent abuse in developing countries as not differing greatly from that in western countries, directly contradicts the experiences of the children in Ruiru, as well as the findings of Kilbride et al. (2000) in Nairobi, Campos et al. (1994) in Brazil and Hussein (2005) in

5. According to the WHO dependence means 'a need for repeated doses of the drug to feel good or to avoid feeling bad' (WHO, 1994). 
Egypt. While Western solvent users generally seek to experience a 'high' as a bounded experience within the course of their normal lives, street children in Ruiru seek to avoid 'normal' consciousness, staying under the influence of solvents for as long as they possibly can. Indeed Josephat suggested that a key reason for glue's popularity was that its cheapness allowed street children to use large quantities and stay high all day.

Tackling solvent dependence amongst street children in developing countries based on observations of Western solvent users is akin to treating alcoholics based on observations of individuals who consume one or two glasses of wine a week; the two patterns of use bear little relation to each other. Dependence, Moore argues, is too often understood as a "measurable psychobiological "it" which can be separated from the social context in which dependence occurs' (Moore, 1992; p. 485). Moore challenges this tendency, proposing that manifestations of substance dependence which occur in different circumstances cannot be treated as the same phenomenon, 'the concept of dependence', Moore suggests, 'makes little sense unless it is situated within a specific social context' (Moore, 1992; p. 485). Hence techniques for addressing solvent dependence in developing countries which are derived from research into solvent use in the West are likely to be ineffectual. 'Street Kids International' another agency working with street-youths has produced a cartoon entitled 'Goldtooth' which is meant to dissuade its audience from using drugs. The makers argue that the film can be used as an educational resource around the world as street children share a 'common culture' (Lowry, 1995; p. 131). The cartoon depicts substance use as being a result of negative peer-pressure from gangs of 'hard core street kids' and parasitic drug dealers who 'manipulate young people and take advantage of their problems' (Lowry, 1995; p. 133). This simplistic representation bares little relation to the social context of solvent dependence in Ruiru, and I imagine it would have little impact on my interviewees at least.

\section{SOLVENTS: A CHALLENGE TO REHABILITATION}

One of the Largest NGOs working with street children in Nairobi, the Undugu society, reports that 'one of the greatest hindrances to street work is the rampant use of substances of abuse among the children on the streets' (Undugu, n.d.). In his analysis of rehabilitation programmes for street children in Nairobi, Mugo suggests that 'the sniffing of glue... made it difficult for the children to adjust to the rehabilitation centres' and that this led to high drop out rates (Mugo, 2004; p. 142). In Ruiru too, solvent use has proved to be a major impediment to rehabilitation attempts. The 'Ruiru Rehabilitation Centre' was opened in 1998 by a local businessman, providing shelter, food and support for thirty boys who had come straight off the street in Ruiru. Gitau and Ndungu were two of these thirty; two of only three of the original boys who remain in the centre today ${ }^{6}$. While some of the boys were successfully rehabilitated many ran away from the centre or were sent away. The primary source of conflict which lead to the high rate attrition seems to have been solvent use. 'There were those rules that were so strict...' explained Gitau, 'if you are caught with glue maybe you could have been caned and this made many childrens [sic] even to go back to the street... even now they are at the street'. The centre still provides a home for around thirty children, but most of these are orphans or children from disadvantaged backgrounds who might otherwise have ended up on the street; the vast majority were never actually street children.

Many rehabilitation programmes are unsuccessful because they fail to appreciate that dependence on solvents is preceded by dependence on 'street-families' for protection and support. In essence they fail to take into account the social context of dependence. In its training package for NGO's working with

6. Josphat attended the Ruiru rehabilitation centre for a time, though he left after a disagreement, went back to the street and then found his way to another Rehabilitation centre in Mombasa were he now lives. 
street children the WHO stresses that for children to stop using solvents, 'positive' attachments need to be developed with 'people and things that are not connected with substance use... Negative attachments are connections to people or institutions that are associated with substance use' (WHO, 2000a; p. 39). This distinction between 'positive' and 'negative' attachments might be relevant to programmes tackling drug use in the West, but in the context street children in developing countries it is misleading and unhelpful. As has been demonstrated, the attachments street children have to other street children in the 'street family' are largely positive and supportive; more than this they are vital to a child's survival. Yet these are the same attachments which lead to intense pressure to use glue. Approaches which set out to divide street children from the 'bad influence' of street families are bound to failure in a large number of cases as they fail to appreciate the dependence of the former on the latter.

International, state and non-governmental initiatives to rehabilitate street children offer a conditional salvation to a chosen few. They can help a few individuals but do little to address the deep structural roots of child homelessness and hence have a negligible impact on the numbers of children living on the streets. The Undugu society, for example, works with 300 children a year; a tiny fraction of Nairobi's estimated 60,000 street children (Undugu, n.d.). In 1996 the WHO 'Special project on street children' reported that it worked with 5000 children globally (WHO, 1996; p. ii); approximately $0.05 \%$ of the worlds street children. Even the support which is available to the minority can often prove to be fragile and short lived. One of the NARC governments promises when it swept to power in 2003 was to provide centres and homes for Nairobi's street children. Six centres were opened, but by 2006 only two of these were still operational. The East African Standard reports that 'of about 500 children who were initially at [one of the remaining centres] only 90 are still hosted there... Occupants of the closed centres have since gone back to the streets' (East African Standard, 2006).
The 'street-family' is a response to exclusion, neglect and poverty, the support which it offers is vital to the survival of thousands of children who left alone on the streets might very well perish. It would be extremely unwise for a street child to break or jeopardise attachments with the 'street-family' by rejecting glue, unless they were $100 \%$ certain that they could rely on the NGO or other organisation promising assistance. Given the limited scope and poor track record of many state and nongovernmental organisations, it is understandable that many do not have enough faith in rehabilitation programmes to give up solvents. Children may justifiably view the support and care offered by rehabilitation programmes to be more fragile and conditional than that received from the 'street-family', and therefore resist the attempts of well intentioned individuals to stop them using solvents for fear of weakening their bond with the street-family. Indeed it is significant that while Gitau and Ndungu lived on the street for many years, they had maintained some level of contact with their mothers; this family attachment may have made it easier for them to take the risk of giving up glue than for children who were totally dependent on their 'street family'. It would be interesting to observe whether initiatives which focused on the unit of the 'street-family' rather than on the individual enjoyed a higher degree of success. A programme which did not place children in conflict with their peer-group would make the children feel more secure and would likely show lower drop-out rates.

\section{CONCLUSION}

Until the structural roots of child homelessness, outlined at the start of this paper, are addressed, the continued use of solvents by street children is inevitable. In the context of entrenched poverty solvents offer some relief, both in their chemical effects and in the link they provide to the support structure of the street family. Current efforts to rehabilitate street children will not solve the wider structural problems, but projects could be made more 
effective by acquiring a more nuanced understanding of youths' relationship with solvents. It is essential that more research is conducted in this field to enable agencies working with street children to take a more evidence-based approach. Initiatives need to be informed by social context in which dependence takes place, and cannot 'import' rehabilitation models from dramatically different Western contexts. It is likely that programmes which conducted rehabilitation through the group, rather than in opposition to it, would encounter far less resistance and enjoy a higher degree of success.

\section{REFERENCES}

Aptekar, L. (1991). Are Colombian Street Children Neglected? The Contributions of Ethnographic and Ethnohistorical Approaches to the Study of Children. Anthropology \& Education Quarterly, 22(4), 326-349

Buxton, J. (2006). The Political Economy of Narcotics. London: Zed.

Campos, R. Marcela Raffaelli, M. Walter Ude, W. Ruff, A. Rolf, J. Antunes, C... de Zalduondo, B. (1994). Social Networks and Daily Activities of Street Youth in Belo Horizonte, Brazil. Child Development, 65(2), 319-330

Consortium for Street Children, (2004). Kenya. Retrieved from www.streetchildren. org.uk/resources/ details/?type $=$ country \& country=14 March 2009

Davis, M. (2004). Planet of Slums. New Left Review, 26,5-35

East African Standard, (2006). From street boys to men, July 30, 2006, p. 13.

Hussein, N. (2005). Street children in Egypt: group dynamics and subcultural constituents. Cairo: American University in Cairo Press.

Mugo, J. K. (2004). Rehabilitation of street children in Kenya. London: IKO, Verlag für Kulturelle Kommunikation.

Kilbride, P. Njeru, E. Suda, C. (2000). Street children in Kenya: voices of children in search of a childhood. London: Bergin \& Garvey.
Komter, A. (2005). The gift : an interdisciplinary perspective. Amsterdam: Amsterdam University Press.

Lowry, C. (1995). Reaching street youth on substance abuse. World Health Forum, 16(2), 131-134

Lalander, P. (2003). Hooked on heroin: drugs and drifters in a globalized world. New York: Berg.

Moore, D. (1992). Deconstructing "dependence": An ethnographic critique of an influential concept. Contemporary Drug Problems, 19(3), 459-490

Sahlins, M. (1972). Stone age economics. Chicago: Aldine-Atherton.

Scheper-Hughes, N. (1998). Small wars : the cultural politics of childhood. Berkeley: University of California Press.

Suda, C. (1997). Street Children in Nairobi and the African cultural ideology of kin-based support system. Child Abuse Review, 6, 199-217.

Undugu, (n.d). Programmes of Undugu Society of Kenya. Retrieved from www.undugukenya.org/ programmes.php December 2008.

UN-HABITAT, (2003). Slums of the World: The face of Urban Poverty in the New Millennium, Nairobi: UN-HABITAT.

UNODCCP (1999). The drug nexus in Africa. Vienna: UNODCCP.

U.S. Congress, (1994). Technologies for Understanding and Preventing Substance Abuse and Addiction, Washington DC: U.S. Government Printing Office.

Venkatesh, A. (1997). The Social Organization of Street Gang Activity in an Urban Ghetto. The American Journal of Sociology, 103(1), 82-111

Watson, J. (1986). Solvent abuse : the adolescent epidemic? London: Croom Helm.

World Health Organization, (1992). Solvent abuse: report of WHO consultation. Geneva: WHO Programme on Substance Abuse.

World Health Organization, (1993). A OneWay Street? Report on phase I of the street children project, Geneva: WHO Programme on Substance Abuse. 
World Health Organization, (1994). Lexicon of Alcohol Drug Terms, Geneva: WHO.

World Health Organization, (1996). A TwoWay Street? Report on phase II of the street children project, Geneva: WHO Programme on Substance Abuse.

World Health Organization, (2000a). Working With Street Children: Module 3. Geneva: Department of Mental Health and Substance Dependence.
World Health Organization, (2000b). Working With Street Children: Module 8. Geneva: Department of Mental Health and Substance Dependence.

World Health Organization./National Institute on Drug Abuse. (2000). Street Children and Drug Abuse: Social and Health Consequences. Retrieved from http://www. drugabuse.gov/pdf/streetchildren.pdf February 2009. 